\title{
NATURAL RESOURCES, FUEL EXPORTS AND CORRUPTION POLICY IN AFRICA
}

\author{
VINCENT A ONODUGo, DAVID OLUFEMI ISIJOLA ${ }^{l}$
}

\begin{abstract}
Theoretical explanations of corruption in Africa are inconclusive. Economic downturn and poverty are the effects of poor resource management in Africa. Yet, neopatrimonialism also stands as an alternative explanation. This survey differentiates these two theoretical alternatives to understanding corruption in Africa. It examines 54 African countries using the corruption perception index of 2017, finding that fuel-exporting countries in Africa are more corrupt than non-fuel exporting countries, with a large associated effect size (Cohen's $d=.94)$. The situation of fuel-exporting countries may be linked with resourcecurse theory (poor resource management) and the extractive theory of corruption (neopatrimonialism), while that of non-fuel-exporting countries only with the extractive theory of corruption (neopatrimonialism). African nations involved in the exportation of fuel resources are 94\% more likely to be more corrupt than those that are not.
\end{abstract}

KEYWORDS: Natural resources, Dutch disease, fossil fuels, oil price, embezzlement

\section{INTRODUCTION}

A natural resource endowment provides a valuable flow of income to a country, helps economies to grow rapidly and prosper, and supports a high standard of living (Pendergast - Clarke - van Kooten, 2008; Li, 2013; Cronin - Pandya,

1 Vincent A Onodugo is Associate Professor at Department of Management, University of Nigeria, Enugu Campus, email: vincent.onodugo@unn.edu.ng, David Olufemi Isijola works at Department of Business Administration, Federal University of Technology, Akure, email: doisijola@gmail. com. 
2009). Despite these benefits, countries endowed with natural resources are often outperformed in terms of economic development, long-term economic growth, and poverty reduction by countries that are not naturally rich in the former (Li, 2013; Sachs - Warner, 1995;1997). The situation of Africa, particularly Sub-Saharan Africa, is an example of how natural resource endowments can suffocate development and distract the government from the central task of ensuring long-term prosperity (Timms, 2016).

Resource Curse theory gives a possible explanation for this paradox; it suggests that economies that produce mineral resources may become distorted due to their vulnerability to shocks from additional and unforeseen profits that are generated by exports (Weeks, 2012). It explains that public expenditure is more effectively used for development in countries that lack natural resources because their citizens (who are directly responsible for generating these funds) scrutinize government spending. In contrast, government spending is not scrutinized the same way by citizens of resource-rich countries because extractive industries rather than citizens pay taxes, royalties, and other payments to generate the public funds needed for development (Silje, 2007; Kelley, 2012). This laxity on the part of the citizenry makes an economy vulnerable to the exploitation of extractive industries by governments through rent-seeking behaviour and the prodigal use of public funds which, when exchanged via foreign platforms, deplete national wealth (NRGI Reader, 2015; Ades - Di, 1999; Azfar - Lee Swamy, 2001; Pendergast - Clarke - van Kooten, 2008). Nigeria, the Republic of Congo, Equatorial Guinea, and Angola are examples of such economies that experience conflict, inefficient spending, and borrowing, "Dutch disease," weak institutional development, and social/environmental problems due to the resource curse (Kuzu - Nantogmah, 2010; Durovic, 2016; Basedau, 2005; Arazki - van der Ploeg, 2010). Regardless of this, Botswana sets the stage for a debate about whether natural resources represent a blessing or a curse (Basedau, 2005). Even though it is the largest producer of diamonds in the world, Botswana has used its earnings to promote economic growth, address social needs, and stabilize its economy (Li, 2013; Kuzu - Nantogmah, 2010). Because of this, the example of Botswana puts the spotlight on African economies that are naturally endowed but unable to improve the national standard of living. This suggests that the relationship between natural endowment and living standards remains extremely complicated (Pendergast - Clarke - van Kooten, 2008).

In recent times, research scientists have become intrigued by natural-resourcerelated questions such as (Stijns, 2005; Basedau, 2005) whether countries with natural resources are blessed or cursed, why do resource-rich countries like Nigeria and Angola suffer from the resource curse, whereas Botswana, the world's largest producer of diamonds, enjoys the benefits of its resources, and 
is there any explanation for the resource curse. Pendergast - Clarken - van Kooten (2008), Kelley (2012) and Li (2013) advocate, amongst other things, that corruption, defined as the abnormal use of entrusted power for private gain (Transparency International, 2018; Nye, 1967), is the primal reason for the resource curse. They show that having a natural resource endowment is not inherently a curse, but the resource curse transpires due to corrupt government officials who reside in resource-rich countries because the latter fail to account for the transparent expenditure of public funds and to protect their citizens from theft. Consequently, countries that entertain corrupt governments suffer from stunted economic growth, mass poverty, poor development, and weak institutions (Li, 2013).

Natural resources do not inevitably represent a curse to countries that are resource rich (Basedau, 2005). However, the type of natural resource can affect a nation's vulnerability to corruption and validate resource curse theory (Salai-Martin - Subramanian, 2003; Collier - Hoeffler, 2005). Pendergast - Clarke van Kooten (2008) found that the existence of fuel resources increases potential corruption as opposed to ore resources (e.g. diamonds), which appear to reduce corruption. Therefore, they consider a fuel resource as a "curse" and ore resources as a "blessing." Their finding explains why Botswana and Nigeria are at opposite ends of the scale regarding living standards and economic growth (Humphreys - Sachs - Stiglitz, 2007).

\section{FUEL EXPORTATION IN AFRICA}

Two-thirds of fuel products are traded across international borders (Ruta - Venables, 2012). Fuel-exporting countries enjoy the receipt of tax on fuel exports, fuel subsidies, and a lower domestic fuel price relative to the world price (Ruta - Venables, 2012). Ironically, as a country's oil-resource wealth increases, so does its inducement to corruption, instability, and patronagedriven politics (Gillies, 2009; Timms, 2016). Studies show that the vulnerability of oil resource-rich countries to price instability and government exploitation are associated with higher levels of rent-seeking behavior, corruption, and internal conflict (Pendergast - Clarke - van Kooten, 2008; Fearon, 2005; Leite - Weidmann, 1999; Van der Ploeg - Poelhekke, 2009). For instance, the removal of fuel subsidies in 2012 by the federal government of Nigeria led to internal conflict and public protests characterized by strikes by oil and non-oil workers, which invariably threatened the shutdown of all oil production in the country (EIA, 2012; Agbon, 2016). Furthermore, a court case involving the Vice 
President of Equatorial Guinea in 2017 was related to corruption, as he was convicted of plundering public money from his oil-rich resource country to fund a jet-set lifestyle in Paris (Chrisafis, 2017). Similarly, the luxurious lifestyle and prodigal spending of government funds by a top government official from the oil-rich republic of Congo instigated bribery-related investigations involving an Australian company and corrupt officials from the Republic of Congo (McKenzie - Freudenthal - Bachelard - Baker, 2016). These instances illustrate some of the fundamental reasons for a country's negative economic performance, particularly when political elites perceive resource booms as temporal and become avaricious of benefitting from them (Robinson - Torvik - Verdier, 2006). There are three fundamental elements of the resource curse: resource abundance, oil and gas resource dominance, and poor economic performance (Kuzu - Nantogmah, 2010; Basedau, 2005).

The effect of the resource curse is detrimental because it influences a country's socioeconomic development, quality of institutions, governance, and prospects for democracy and human rights, as well as peace and security (Basedau, 2005; Kuzu - Nantogmah, 2010; Li, 2013). These effects are contingent on three simultaneous factors that occur due to the resource curse (Kelley, 2012; Aghion - Banerjee, 2005; Mehlum - Moene - Torvik, 2005; Deacon - Rode, 2015): 1) Dutch disease, 2) vulnerability due to price volatility related to commodity dependence, and 3) weak governance and poor institutional quality.

So-called Dutch disease manifests when a country that is naturally resource rich tries to raise the value of its currency by diverting the majority of its production factors towards the uncompetitive exportation of a natural resource. Consequently, Dutch disease is contingent on two situations. The first is a reduced revenue flow due to subsequently higher prices of a country's natural resource in the global market that invariably decrease international demand (Kelley, 2012). The second is the inflation of local sales of other commodities in an economy due to the limited supply of production factors needed to create an abundant flow of goods at above the level of demand. Wit \& Crookes (2013) illustrated the Nigerian case of Dutch disease. They explain, supported by Amadeo (2017), that the country's over-dependence on its oil-resource revenue prompted a rise in oil prices in the international market that benefited government spending and fuel subsidy rates. In 2011, over 70 percent of Nigeria's revenues came from oil exports (worth $\$ 99$ billion), but the country failed to invest in other areas of its economy such as agricultural production (Ohuocha - Akwagyiram, 2016; BusinessNews, 2015; News Editor, 2014). Thus, agricultural products were locally sold by oligopolies at inflated rates since they could not compete globally due to weak investment in agricultural infrastructure (Ohuocha - Akwagyiram, 2016). In December 2014, the country's inflexibly high oil prices presented 
the nation with a revenue crisis due to its inability to sell 35 million barrels of oil to international markets (Okere, 2015; Okumagba, 2014; BusinessNews, 2015). At the same time, the production of crude oil declined by 17,300 and 700,000 barrel per day in 2014 and 2016, respectively (Okere, 2015; Ohuocha - Akwagyiram, 2016). In 2016, Nigeria was officially reported to have slid into economic recession caused by Dutch disease due to an increase in the price of food and a revenue crisis (Ohuocha - Akwagyiram, 2016). Nigeria's experience shows that the internal inflation of local sales and a simultaneous decline in revenue flow threatens the long-term economic sustainability of countries that face the resource curse.

Another element of the resource curse manifests when a significant proportion of a country's revenue is derived from the exportation of a single commodity that is vulnerable to price fluctuation. An empirical study by Van der Ploeg Poelhekke (2009) found that most commodity-dependent countries experience economic underdevelopment due to price volatility. For resource exporters, price volatility is another major factor that increases the resource curse (Ruta - Venables, 2012). For instance, a fall in the global oil price of more than 60 percent between June 2014 and January 2015 resulted in a decline in the revenue of oil-exporting countries (BusinessNews, 2015). Records show that the net oil export revenue of members of the Organization of Petroleum Exporting Countries (OPEC), excluding Iran, declined by 11 percent (from $\$ 824$ billion to $\$ 730$ billion) in 2013 (BusinessNews, 2015). This price shock made these oildependent countries vulnerable to threats, which reduced their revenue flow and drove away foreign investors (News Editor, 2014; Okere, 2015).

The quality of institutions and governance is another widely hypothesized driver of the resource curse (Kuzu - Nantogmah, 2010; Silje, 2007). The way a government manages its revenue determines the future state of its economy (Pendergast - Clarke - van Kooten, 2008). Arguably, a country's petrodollar earnings can be responsible for weakening the social contract between citizenry and the government (Kuzu - Nantogmah, 2010). Evidence from pooled timeseries cross-national data from 113 states between 1971 and 1997 showed that oil wealth constrains democratization (Ross, 2001). Natural-resource-dependent countries are more likely to be dictatorial, exhibit higher levels of government spending, poor governance, and are more prone to a breakdown in democracy (Silje, 2007). For oil-exporting countries, Kurecic - Lulic - Kozina (2015) and Tsui (2010) showed that a development in governance and institutional frameworks is essential at the time petrodollar earnings significantly increase, because the absence of the latter can intensify the negative effects of oil discovery on democratization. Without appropriate institutional frameworks, economies can become overwhelmed with lawlessness and corruption due to rent-seeking 
behaviour (Anderson - Hill, 2005). Scholars have explained that the existence of the oil-resource curse is contingent on bad political governance (Arezki Gylfason, 2011; Mehlum - Moene - Torvik, 2005). For example, countries in the Gulf of Guinea that found oil at a time when their democratic institutions were undeveloped were plagued with corruption and repression. Furthermore, Kurecic - Lulic - Kozina (2015) have explained how ruling elites, who failed to govern their countries properly, stole a considerable proportion of oil revenue from countries in the Gulf of Guinea. As a result, the resource curse arose due to the misappropriation of revenue by corrupt leaders and officials $(\mathrm{Li}, 2013)$. Corruption and rent on fuel resources have been proven to negatively affect overall standards of living across countries (Sala-i-Martin - Subramanian, 2003; Azfar - Lee - Swamy, 2001). However, improving institutional quality can help reduce this negative consequence (Pendergast - Clarke - van Kooten, 2008).

\section{CORRUPTION IN AFRICA}

In Africa, corruption is largely a governance issue, resulting from failed institutions and inadequacy of the use of capital to manage society through a framework of social, judicial, political, and economic authorizations (Gbetnkom, 2012). The increasing desire to transcend impoverishment through private wealth-seeking behavior has made corruption pervasive (Gbetnkom, 2012; Eke - Monoji, 2016). Despite being a notable symptom of the resource curse, corruption still presents itself when individuals with the discretion to make decisions fail to account for their use of monopolized power over gainful resources (Klitgaard, 1988). In such instances, corruption occurs through bribery, fraud, nepotism, favoritism, cronyism, and tribalism in the form of the deceitful accumulation and abuse of entrusted wealth or power for selfish interests (Eke - Monoji, 2016). This brand of corruption has its roots in poverty and power, not in countries' natural resources (Stuckelberger, 2003).

Corruption takes the form of a state-society relationship whereby public officials seek ways to bypass legal competition and obstruct the rules of normal societal functioning in order to generate a flow of resources from society to state (Gbetnkom, 2012). The corruption of public officials involves two activities (Gbetnkom, 2012): the first is influencing the choice of products that are supplied to the state and the contract modalities of suppliers at the economic level. The second is using the power of office to indulge in financial fraud and take advantage of segregated amenities, such as access to privileged schools, 
sound medical attention, good housing and lodging, or access to the shares of enterprises undergoing privatization. For instance, reports have illustrated cases of the corruption of African presidents using their offices to influence political appointments and win lucrative state contracts in favor of close relatives and friends (Cotterill, 2018; Nnanna, 2017; Dentlinger, 2018; Magubane, 2018; Calland - Law, 2018). Reports have elucidated how the African continent lost \$ 850 billion between 1970 and 2008 due to fraudulent schemes by governments and multinational companies (Anderson, 2015; Hassan, 2017; Mosselmans, 2014). Estimates revealed that a total of $\$ 217.7$ billion, \$ 105.2 billion, and \$ 81.8 billion was illegally transferred out of Nigeria, Egypt, and South Africa (respectively) during that same period (Anderson, 2015). These practices create poverty and reduce the national standard of living because they deplete fiscal revenue and alter the composition of public expenses (Tanzi - Davoodi, 1998; Gbetnkom, 2012).

The theory of extractive corruption provides a potential explanation for this form of corruption by re-emphasizing the observation that "all power tends to corrupt, and absolute power corrupts absolutely" (Amundsen, 1999). This elucidates the situation in which a state becomes the strongest force in society, the ruling elite acquires dominant control over state powers, and the apparatus of the state is used as an instrument to extract resources from society for the benefit of rulers (Amundsen, 1999). This theory is derived from the political science notion of authoritarianism, which describes how rulers use the power capabilities of the state to attain, retain, and increase their power in order to accumulate resources from the nation for personal benefit (Amundsen, 1999). It can also be traced back to the neo-patrimonial political systems found in Africa, whereby rulers maintain authority through personal patronage rather than ideology or law (Amundsen, 1999). This neo-patrimonial political system undermines economic reform because it involves a life-threatening struggle (at all levels of society) to obtain access to state resources through patronage, clienteles, and rent-seeking (Van de Walle, 2005; Bayart, 2009; Dawson - Kelsall, 2011; Medard, 2002; Soest, 2007). As a result, the theory of extractive corruption defines corruption as an obstinate symptom of neopatrimonialism that plagues African states (Medard, 2002; Kratt, 2015; Beresford, 2014).

Despite being an obstinate plague, corruption has further advanced in most African states (Kratt, 2015). African political elites now use anti-corruption campaigns as legal-rational justification to discredit their opposition and legitimize their corrupt practices (Soest, 2007; Edwards, 2017). A classic example, as reported by Paget (2017), is the Tanzanian anti-corruption crusade. According to Paget's report, after the fifth president of Tanzania 
was sworn into office on 5 November 2015, an anti-corruption campaign was ushered in against civil servants and highly positioned elites of the then opposition party to win the admiration of the world. However, in 2016, after discrediting the opposition and gaining international approval, the president legitimized corruption. The president's legislature undermined legal and parliamentary freedom, actualized fractional bans on open rallies, badgered mobile police authorities, shut down online political spaces, and indicted whistle-blowers under new maligning and dissidence laws. Consequently, the case of the fifth president of Tanzania validates the neo-patrimonial explanation of corruption.

Neopatrimonialism provides the best explanation for corruption in African politics and governance (Mkandawire, 2015), and is characterized by three elements (Ganahl, 2013). The first is presidentialism - a situation where leaders, particularly in Africa, go beyond the narrow sense of political control to portray themselves as "fathers of the nation" by retaining the presidency for decades in other to authenticate the idea that a president is not a mere placeholder in office, but rather a founding father with the ability to make key decisions without the agreement of the legislature or courts (Ganahl, 2013). Prominent followers of this strategy include heads of states in Equatorial Guinea, Angola, Zimbabwe, Cameroon, and Uganda (Hanna, 2017). Second, clientelism - an exchange relationship between unequal parties that politically benefits the agent that is more powerful and offers them material advantage in relation to the less powerful agent (Eisenstadt - Lemarchand, 1981). Predominant in resource-poor African states, most state agents feel they have the right to subvert the rule of law by strategically allocating state revenues to their supporters, co-religionists, and members of their own ethnic groups in exchange for political patronage (Brun - Diamond, 2014; van de Walle, 2007). Gebreluel - Bedasso (2018) have reported how party and state structures in Ethiopia used state resources to maintain and increase party membership from around 700,000 in 2005 to 7,000,000 in 2015. They also showed how state rents were tied to political and bureaucratic appointments through ethnicbased patronage structures, explaining that party officials and political elites mobilize the support of their ethnic constituencies through the assurance of treaty maintenance centered on promoting ethnic interests and the power to oppress the opposition. The third factor is state resource control-i.e. authority and discretion over the use of states' economic resources (Ganahl, 2013). This factor has been cited as one of the primary causes of the failure of growth in the developing world, especially in sub-Saharan Africa. Arguably, African state agents often use state resources to maintain personal control over the government rather than investing in basic infrastructure that would create the 
critical conditions for accelerated development (Paget, 2017). Perhaps this is the reason why the forty-fourth President of the United States criticized African leaders in his address to the African Union in 2015 (Manson, 2015). Although neopatrimonal corruption is widespread in Africa, Botswana has proven to be an exception. Despite being influenced by elements of neopatrimonialism (Pitcher - Moran - Johnston, 2009; Soest, 2009), the country has avoided the major pitfalls that led to the demise of other African countries (Meyns Musamba, 2010). Botswana has maintained a high level of transparency and accountability to keep levels of corruption low and to achieve its development objectives within a democratic system governed by neopatrimonial exchanges of trust (Pitcher - Moran - Johnston, 2009). Consequently, in 2018, Botswana was ranked by the Transparency International Corruption Perceptions Index as the least corrupt country in Africa (Aljazeera, 2018). Botswana's triumph over corruption may provide other African states with the framework that is needed to combat corruption. However, success at replicating Botswana's anti-corruption framework in other African countries may be problematic due to contextual differences. On this note, Ganahl (2013) opines that anticorruption policies should be tailored to the peculiarities of corruption in each African state.

\section{FUEL EXPORTS AND CORRUPTION}

Malfunctioning government institutions have been found to severely harm economic performance by reducing both incentives and opportunities to invest and innovate (North, 1990; Shleifer - Vishny, 1993). Among the different aspects of governance, corruption has received particular attention from both policymakers and researchers. Thus, understanding the role that various types of exports have on corruption has been the fundamental rationale for empirical studies on resource exports and corruption. Scholars have argued that the severity of the resource curse in malfunctioning government institutions depends on the kinds of resources that are valuable in relation to a country's revenue. The former have suggested that point-source resources such as minerals and fuels are more problematic because their centralized control can generate rents that are easily appropriable (Sala-i-Martin - Subramanian, 2003; Boschini - Petterson - Roine, 2007). One such study, conducted by Leite and Weidmann (1999), argued that natural resource abundance is an important factor in determining a country's level of corruption because it creates opportunities for rent-seeking behavior. With the help of a corruption regression equation, 
their study established that capital-intensive natural resources (such as fuel and ores) tend to induce higher levels of corruption compared to labor-intensive resources. Their study constituted the first step toward investigating natural resources and corruption. In context, their results create a model with which to guide government anti-corruption policies.

A more recent study by Goel - Korhonen (2011) examined the relationship between export structure and corruption across nations. The study used ordinary least squares, quantile regression, and two-stage least squares methods to derive a model estimate for corruption across nations. The model showed that economic prosperity, political freedom, economic freedom, government size, fractionalization, and exports are all factors that determine the level of corruption. It also demonstrated that fuel exports and corruption in the most corrupt nations are statistically positively related. The authors argue that the varied direction and magnitude of the effects of various resource types on corruption, such as anti-corruption policies, must be tailored to fit the specific resource types. Though bad management of fuel-resource-related gains may signal a clear danger to economic prosperity and poverty reduction, theoretical explanations are inconclusive. Therefore, by proposing that fuel-exporting countries are more corrupt than non-fuel-exporting countries in Africa, the current study provides empirical evidence in support of the extractive theory of corruption and the resource curse theory. Such evidence also offers potential insights into the formulation of effective policies that could help control the level of corruption in fuel resource-rich countries, particularly Africa, and offers support for theoretical frameworks that best explain corruption in the African context.

\section{MATERIALS AND METHODS}

\section{Participants}

Corruption was used as the dependent variable of the study because it has been identified as widespread in Africa (Pitcher - Moran - Johnston, 2009; Shleifer - Vishny, 1993). A total population of 54 African nations participated in the study. Study participants were classified into fuel-exporting countries and non-fuel-exporting countries, as identified by the United Nations (2017). Out of the 54 countries that participated in the study, 12 were major exporters of fuel. The sampling frame for fuel-exporting and non-fuel-exporting countries is illustrated in Table 1 and Table 2, respectively. 


\section{Procedure}

The study employed an independent samples $t$-test to answer the question whether fuel-exporting countries differ significantly in the prevalence of corruption compared to non-fuel exporting countries. Secondary data was obtained from Transparency International (2018) to measure the prevalence of corruption. The study hypothesized that the prevalence of corruption in fuelexporting countries is not equal to that in non-fuel-exporting countries in Africa $\left(\mathrm{H}_{1}\right)$ against the null hypothesis that corruption is equal in the two groups of countries. More precisely, due to the inverse coding of the corruption perception index (CPI) used to assess corruption, it is expected that fuel-exporting countries are associated with statistically significantly higher corruption (more negative CPI scores) than non-fuel-exporting countries in Africa.

\section{Measures}

Corruption was measured using scores for 2017 from the Corruption Perceptions Index (CPI). The CPI was established in 1995 as a composite indicator for measuring the level of corruption perceived in the public sector worldwide. CPI ranks corruption on the scale of 0 (highly corrupt) to 100 (very clean) based on the assumption that all countries are corrupt to varying degrees. Lower-ranked countries are plagued with higher levels of corruption and suffer from untrustworthy and badly functioning public institutions such as police and judiciary. Higher-ranked countries tend to have lower levels of corruption and enjoy greater press freedom, access to information about public expenditure, stronger standards of integrity for public officials, and independent judicial systems, but may still engage in closed-door deals, illicit financing, and unreliable law enforcement that can distort public policy and exacerbate many forms of corruption at home and abroad. For more information on the methodology and reliability of CPI, see Transparency International (2017). CPI has been validated by Wilhelm (2002) through correlational studies that find strong significant connections between two measures of corruption and real gross domestic product per capita (RGDP/Cap).

\section{Statistical Analysis}

The parameters of the study were described using frequency distributions, means, standard deviations, skew, kurtosis, and a bar chart. Furthermore, 
inferences were drawn using the independent samples t-test, Levene's $F$ test, and Cohen's $d$. Descriptive and inferential statistical analysis was undertaken with the use of Microsoft Excel 2016 and SPSS version 21.

\section{RESULTS}

Fuel-exporting countries $(\mathrm{N}=12)$ are associated with a corruption perception index $\mathrm{M}=24.58(\mathrm{SD}=7.20)$. By comparison, non-fuel-exporting countries ( $\mathrm{N}$ $=42$ ) are associated with a numerically greater corruption perception index $\mathrm{M}$ $=34.23(\mathrm{SD}=12.26)$. To test the hypothesis that fuel-exporting countries are associated with statistically significant more negative corruption perception index scores than non-fuel-exporting countries in Africa, an independent samples t-test was performed. As can be seen in Table 4, the fuel-exporting and non-fuel exporting distributions were sufficiently normal to permit the implementation of a $t$-test (i.e., skew $<|2.0|$ and kurtosis $<|9.0|$; Schmider Ziegler - Danay - Beyer - Buhner, 2010). Additionally, the assumption that variances were homogenous was tested and satisfied via Levene's $F$ test, $F(1,52)=2.95, \mathrm{p}=.092$. The independent samples t-test was associated with a statistically significant effect, $t(1,52)=-2.59, \mathrm{p}=.006$ (one-tailed). Cohen's $d$ was estimated at .85, which is a large effect based on Cohen's (1992) guidelines. A graphical representation of the means and the $95 \%$ confidence intervals is contained in Figure 1. The study found that there is a $95 \%$ chance that the mean difference lies between -17.13 and -2.18 , which does not include zero. Thus, the study did not support the null hypothesis that the prevalence of corruption in fuel-exporting countries is the same as non-fuel-exporting countries in Africa. Thus, $\mathrm{H}_{1}$ is supported. The study found that there is a significant difference in the prevalence of corruption between fuel-exporting and non-fuel exporting countries (a mean difference of 0 ).

\section{DISCUSSION}

Fuel-exporting countries were found to be more corrupt than non-fuelexporting countries in Africa. This proposition supports resource curse theory and gives insights into the implication of fuel exportation and corruption levels.

The results clearly indicate that fuel exportation is positively associated with significant levels of corruption. By implication, increases in fuel exportation 
also translate into a significant increase in corruption. Prior to this study, Goel - Korhonen (2011) established a model to estimate the relationship between resource exports and corruption. Furthermore, Leite - Weidmann (1999) evaluated the relationship between capital- and labour-intensive natural resources (such as fuel, ores, food, and agriculture) on corruption. Their studies enumerated various factors that have statistical effects on corruption. However, their studies did not compare significant differences in corruption between fuel- and non-fuel exporting countries. Research from Leite - Weidmann (1999) categorized fuel and ores as capital-intensive natural resources that play a role in increasing corruption, but the findings were unable to determine the unique contributions of fuel exportation to corruption. The current study represents a unique contribution to the corruption literature by determining that fuel-exporting countries are significantly more likely to be associated with corruption compared with non-fuel exporting ones. However, the study did not establish causality between fuel-exportation and corruption. The study has also contributed to the literature by providing evidence within the African context that helps distinguish theoretical explanation of corruption. It identifies poor resource management as a distinguishing element of the difference in corruption between fuel-exporting countries and non-fuel-exporting countries in Africa. Theoretically, African countries that export fuel do badly in terms of resource management because of the kind of resource that dominates their export portfolio. To reduce corruption levels, fuel-exporting parts of Africa must formulate fuel-specific policies that address poor resource management (the extractive theory of corruption). Perhaps a more diversified export portfolio characterized by a significant proportion of non-fuel exports may reduce the presence of corruption and restrict the manifestation of the resource curse. Contingent on the limitations of this study, future studies are advised to focus on a wider sample of developing economies.

\section{REFERENCES}

Ades, A. - Di, T. R. (1999), "Rents, Competition, and Corruption", American Economic Review, Vol. 89, No. 4, pp. 982-993. doi:https://doi.org/10.1257/ aer.89.4.982

Agbon, I. (2016, January 2), "Nigeria: Subsidy Removal and Fuel Price Increase By IMF Price Modulation", The Guardian. Retrieved January 11, 2019, from https://guardian.ng/saturday-magazine/subsidy-removal-and-fuel-priceincrease-by-imf-price-modulation/ 
Aghion, P. - Banerjee, A. (2005), Volatility and growth. Oxford University Press. doi:https://doi.org/10.1093/acprof:oso/9780199248612.001.0001

Aljazeera. (2018, February 02), "How does Botswana fight corruption in Africa?" Aljazeera. Retrieved January 11, 2019, from http://www.aljazeera. com/news/2018/02/botswana-fight-corruption-africa-180202133111611.html

Amadeo, K. (2017, December 12), "What Makes Oil Prices so High", the balance. Retrieved January 11, 2019, from https://www.thebalance.com/whatmakes-oil-prices-so-high-3305654

Amundsen, I. (1999), Political Corruption: An Introduction to the Issues. Bergen: Norway: Chr. Michelsen Institute. Retrieved January 11, 2019, from https://www.cmi.no/publications/1040-political-corruption

Anderson, M. (2015, Febuary 2), "Africa losing billions from fraud and tax avoidance", The Guardian. Retrieved January 11, 2019, from https://www. theguardian.com/global-development/2015/feb/02/africa-tax-avoidancemoney-laundering-illicit-financial-flows

Anderson, T. L., - Hill, P. J. (2005), The not so wild, wild west: Property rights on the frontier. North America: Stanford University Press.

Arazki, R. - van der Ploeg, F. (2010), "Trade policies, institutions and the natural resource curse", Applied Economics Letters, Vol. 17, No. 15, pp. 14431451. doi:https://doi.org/10.1080/13504850903035881

Arezki, R. - Gylfason, T. (2011), "Commodity Price Volatility, Democracy and Economic Growth", in: de la Grandville, O. ed. Economic Growth and Development, Emerald Publishing Group, Howard House, pp. 9-24. doi:https:// doi.org/10.1108/S1574-8715(2011)0000011007

Azfar, O. - Lee, Y. - Swamy, A. (2001), "The causes and consequences of corruption" The Annals of the American AcademyofPolitical and Social Science, Vol. 573, No. 1, pp. 42-56. doi:https://doi.org/10.1177/0002716201573001003

Basedau, M. (2005), Context Matters - Rethinking the Resource Curse in SubSaharan Africa, Hamburg: German Overseas Institute (DUI). doi:https:// dx.doi.org/10.2139/ssrn.906983

Bayart, J. F. (2009), The State in Africa: The Politics of the Belly. Cambridge: Polity Press.

Beresford, A. (2014), "Understanding how 'Africa works'?" Critical African Studies, Vol. 6, No. 1, pp. 1-5. doi:https://doi.org/10.1080/21681392.2015.1011442 Boschini, A. - Petterson, J. - Roine, J. (2007), "Resource curse or not: A question of appropriability", Scandinavian Journal of Economics, Vol. 109, No. 3, pp. 593-617. doi:https://doi.org/10.1111/j.1467-9442.2007.00509.x

Brun, D. A., - Diamond, L. (2014), Clientelism, Social Policy, and the Quality of Democracy. Baltimore: Johns Hopkins University Press. doi:https://doi.org $/ 10.1080 / 08854300.2013 .843264$ 
BusinessNews. (2015, April 3), "Nigeria earned \$77bn from oil export in 2014", BusinessNews. Retrieved September 11, 2018, from http://businessnews.com. ng/2015/04/03/nigeria-earned-77bn-from-oil-export-in-2014/

Calland, R. - Law, M. (2018, January 23), "It's becoming clear Jacob Zuma's end is much nearer than we thought", Quartz Africa. Retrieved January 11, 2019, from https://qz.com/africa/1186419/south-africa-gupta-probe-jacob-zumasend-is-very-close/

Chrisafis, A. (2017, October 27), "Son of Equatorial Guinea's president is convicted of corruption in France", The Guardian. Retrieved January 11, 2019, from https://www.theguardian.com/world/2017/oct/27/son-of-equatorialguineas-president-convicted-of-corruption-in-france

Cohen, J. (1992), “A power primer”, Psychological Bulletin, Vol. 112, pp. 155159. doi:https://doi.org/10.1037/0033-2909.112.1.155

Collier, P. - Hoeffler, A. (2005), "Resource rents, governance and conflict", Journal of Conflict Resolution, Vol. 49, No. 4, pp. 625-633. doi:https://doi. org/10.1177/0022002705277551

Cotterill, J. (2018, Febuary 2), "Zuma faces test of ANC support in no-confidence vote this month", Financial Times. Retrieved January 11, 2019, from https:// www.ft.com/content/7a6416d6-1062-11e8-8cb6-b9ccc4c4dbbb

Cronin, R. P. - Pandya, A. (2009), Exploiting natural resources: Growth, instability, and conflict in the Middle East and Asia. Henry L. Stimson Center.

Dawson, M. - Kelsall, T. (2012), "Anti-developmental patrimonialism in Zimbabwe" Africa: Power and Politics, Vol. 30, No. 1, pp. 49-66. doi:https:// doi.org/10.1080/02589001.2012.643010

Deacon, R. T. - Rode, A. (2015), "Rent seeking and the resource curse" Companion to the Political Economy of Rent Seeking, Vol. 227, doi:https://doi. org/10.4337/9781782544944.00022

Dentlinger, L. (2018, January 31), "Lucky Montana: Tony Gupta \& Duduzane Zuma tried to influence train project" Eyewitness News. Retrieved January 11, 2019, from https://ewn.co.za/2018/01/30/lucky-montana-tony-gupta-andduduzane-zuma-tried-to-influence-train-project

Durovic, L. (2016), "Resource Curse and China's Infrastructure for Resources Model: Case Study of Angola", Journal of China and International Relations, Vol. 4, No. 1, pp. 67-86. doi:https://doi.org/10.5278/ojs.jcir.v4i1.1515

Edwards, T. (2017, March 13), "When and Why Do Corrupt Politicians Champion Corruption Reform? A Character Study", The Global Anticorruption Blog. Retrieved January 11, 2019, from https://globalanticorruptionblog. com/2017/03/13/when-and-why-do-corrupt-politicians-champion-corruptionreform-a-character-study/ 
EIA, U. (2012), Annual energy review 2011, Energy Information Administration. Eisenstadt, S. S. - Lemarchand, R. (1981), Political clientelism: Patronage and development (Vol. 3). Sage Publications

Eke, A. A. - Monoji, C. M. (2016), "Blending the Legal and Institutional Framework with the Economy of Communion as a New Paradigm for Fight Against Corruption in Developing African Countries: The Case of Cameroon", Studies in Sociology of Science, Vol. 7, No. 2, pp. 5-21. doi:DOI:10.3968/8557

Fearon, J. D. (2005) "Primary commodity exports and civil war", Journal of Conflict Resolution, Vol. 49, No. 4, pp. 483-507. doi:https://doi. org/10.1177/0022002705277544

Ganahl, J. P. (2013), Corruption, Good Governance, and the African State: A Critical Analysis of the Political-Economic Foundations of Corruption in Sub-Saharan Africa. Potsdam: Potsdam University Press.

Gasiorowski, M. J. (2006), "The Political Regimes Project", in: Inkeles, A. ed. On Measuring Democracy: Its Consequences and Concomitants, Routledge, pp. 110-111. Gbetnkom, D. (2012), "Corruption and small and medium-sized enterprise growth in Cameroon" African Economic Conference, (p. 24). Kigali, Rwanda. Retrieved January 11, 2019, from https://www.afdb.org/fileadmin/uploads/ afdb/Documents/Knowledge/Corruption $\% 20$ and $\% 20$ small $\% 20$ and $\% 20$ medium-sized\%20enterprise\%20growth\%20in\%20Cameroon.pdf

Gebreluel, G. - Bedasso, B. (2018, Febuary 7), "Managing Ethiopia's political crisis", Alijazeera, Retrieved January 11, 2019, from www.alijazeera.com/ indepth/opinion/managing-ethiopia-political-crisis-180205113035729.html

Gillies, A. (2009), Reforming corruption out of Nigerian oil? University of Cambridge, Centre of International Studies. Anti-Corruption Resource Centre. Retrieved January 11, 2019, from https://www.cmi.no/publications/ file/3348-reforming-corruption-out-of-nigerian-oil-part-one.pdf

Goel, R. K. - Korhonen, I. (2011), "Exports and cross-national corruption: A disaggregated examination", Economic Systems, Vol. 35, No. 1, pp. 109-124. doi:https://doi.org/10.1016/j.ecosys.2010.10.002

Hanna, J. (2017, January 19), "Africa's current longest-serving leaders" CNN, Retrieved January 11, 2019, from https:/www.cnn.com/2017/01/19/africa/ africa-gambia-longest-serving-leaders/index.html

Hassan, A. A. (2017, June 18), "Tax evasion and dirty money are draining Africa", The Conversation, Retrieved January 11, 2019, from http://theconversation. com/tax-evasion-and-dirty-money-are-draining-africa-78003

Humphreys, M. - Sachs, J. D. - Stiglitz, J. E. (2007), "Future directions for the management of natural resources", in: M. Humphreys, J. D. Sachs, J. E. Stiglitz eds. Escaping the resource curse, New York: Columbia University Press, Vol. 1, pp. 322-336. 
Kelley, J. (2012), "China in Africa: Curing the resource curse with infrastructure and modernization", Sustainable Development Law \& Policy, Vol. 12, No. 3, pp. 35-42, 57-60.

Klitgaard, R. (1988), Controlling corruption, University of California Press

Klugman, J. - Rodriguez, F. - Choi, H. J. (2011), "The HDI 2010: New Controversies, Old Critiques", The Journal of Economic Inequality, Vol. 9, No. 2, pp. 249-288. doi:https://doi.org/10.1007/s10888-011-9178-z

Kratt, E. (2015), To What Extent is Neopatrimonialism the Unchanging Way in Which 'Africa Works'? Retrieved January 11, 2019, from E-International Relations Students: https://www.e-ir.info/author/elliot-kratt/

Kurecic, P. - Lulic, L. - Kozina, G. (2015), "The Influence of Oil Exports' dependence on corruption and political freedoms in the countries of the gulf of Guinea region", Book of Proceedings, 9th Economic and Social Development Conference, Istanbul, Turkey, 210.

Kuzu, D. - Nantogmah, D. (2010), The Oil Economy and the Resource Curse Syndrome: Can Ghana make a difference? Ghana: Friedrich Ebert Stiftung. Retrieved from http://library.fes.de/pdf-files/bueros/ ghana/10492.pdf

Leite, C. A. - Weidmann, J. (1999), Does mother nature corrupt? Natural resources, corruption, and economic growth. Washington DC: International Monetary Fund

Li, M. (2013, November), "Corruption, Transparency and the Resource Curse", International Journal of Social Science and Humanity, Vol. 3, No. 6, pp. 572575. doi:https://doi.org/10.7763/IJSSH.2013.V3.305

Magubane, K. (2018, January 31), "Let a court test claims of Gupta corruption, Ben Martins insists", BusinessDay. Retrieved January 11, 2019, from https:// www.businesslive.co.za/bd/national/2018-01-31-ben-martins-countersearlier-testimonies-distancing-himself-from-the-guptas/

Manson, K. (2015, July 28), 'Obama criticises Africa's 'strongmen' who refuse to leave office", Financial Times. Retrieved January 11, 2019, from https:// www.ft.com/content/c4c9cc4a-3525-11e5-bdbb-35a55cbae175

McKenzie, N. - Freudenthal, E. - Bachelard, M., - Baker, R. (2016, August 25), "Not-so risky business in Congo as Australians embroiled in offshore bribe claims", The Sydney Morning Herald. Retrieved January 11, 2019, from https://www.smh.com.au/business/notso-risky-businessin-congo-as-australians-embroiled-in-offshore-bribe-claims-20160824gqzsp5.html

Medard, J. (2002), "Corruption in the Neo-Patrimonial States of Sub-Saharan Africa". in: Heidenheimer, A. ed. Political Corruption: Concept and Contexts (3rd Edition). New Brunswick: Transaction Publishers, pp. 379-402. 
Mehlum, H. - Moene, K., - Torvik, R. (2005), "Crime induced poverty traps", Journal of Development Economics, Vol. 77, No. 2, pp. 325-340. doi:https:// doi.org/10.1016/j.jdeveco.2004.05.002

Meyns, P. - Musamba, C. (2010), The Developmental State in Africa: Problems and Prospects, University of Duisburg-Essen and Institute for Developement and Peace

Mkandawire, T. (2015), "Neopatrimonialism and the political economy of economic performance in Africa: Critical reflections", World Politics, Vol. 67, No. 3, pp. 563-612. doi:https://doi.org/10.1017/S004388711500009X

Mosselmans, I. (2014, March 7), "Tax evasion: the main cause of global poverty", London School of Economics and Political Science. Retrieved January 11, 2019, from http://blogs.lse.ac.uk/africaatlse/2014/03/07/tax-evasion-the-maincause-of-global-poverty/

News Editor (2014, October 15), "Nigeria's Economy And Falling Price of Crude Oil”, The Street Journal. Retrieved January 11, 2019, from http://thestreetjournal. org/2014/10/nigerias-economy-and-falling-price-of-crude-oil/

Nnanna, O. (2017, October 9), "Nigeria: Nepotism, Mother of All Corruption", Vangard (Lagos). Retrieved January 11, 2019, from https://www.vanguardngr. com/2017/10/nepotism-mother-corruption/

North, D. C. (1990), Institutions, Institutional Change, and Economic Performance, New York: Cambridge University Press, doi:https://doi. org/10.1017/CBO9780511808678

NRGI Reader (2015, March), The Resource Curse: The Political and Economic Challenges of Natural Resource Wealth, Retrieved January 11, 2019, from https://resourcegovernance.org/sites/default/files/nrgi_Resource-Curse.pdf

Nye, J. S. (1967), "Corruption and political development: A cost-benefit analysis", American Political science review, Vol. 61, No. 2, pp. 417-427. doi:https://doi. org/10.2307/1953254

Ohuocha, C., - Akwagyiram, A. (2016, August 31), "UPDATE 2-Nigeria in recession as low oil prices shrink economy", Reuters, Retrieved January 11, 2019, from https://www.reuters.com/article/nigeria-gdp-idUSL8N1BC1PQ

Okere, R. (2015, January 15), "Nigeria's 35m barrels of crude oil remain unsold", The Guardian. Retrieved January 11, 2019, from https:/guardian.ng/businessservices/business/nigeria-s-35m-barrels-of-crude-oil-remain-unsold/

Okumagba, B. (2014, November 5), "Falling crude oil prices and Nigeria's response", Vangard, Retrieved January 11, 2019, from https://www. vanguardngr.com/2014/11/falling-crude-oil-prices-nigerias-response/

Paget, D. (2017, November 07), “Tanzania's anti-corruption crusader cracks down on opponents", $C N N$, Retrieved January 11, 2019, from https://www. cnn.com/2017/11/07/africa/magufuli-crackdown/index.html 
Pendergast, S. M. - Clarke, J. A. - van Kooten, G. C. (2008), Corruption and the Curse of Natural Resources, University of Victoria, Department of Economics, Victoria, BC.

Petermann, A. - Guzman, J. I. - Tilton, J. E. (2007), "Mining and corruption", Resource Policy, Vol. 32, No. 3, pp. 91-103. doi:https://doi.org/10.1016/j. resourpol.2007.08.003

Pitcher, A. - Moran, M. - Johnston, M. (2009), "Rethinking patrimonialism and neopatrimonialism in Africa", African Studies Review, Vol. 52, No. 1, pp. 125-156. doi:https://doi.org/10.1353/arw.0.0163

Robinson, J. A. - Torvik, R., - Verdier, T. (2006), "Political foundations of the resource curse", Journal of Development Economics, Vol. 79, No. 2, pp. 447468. doi:https://doi.org/10.1016/j.jdeveco.2006.01.008

Ross, M. L. (2001), “Does Oil Hinder Democracy?”, World Politics, Vol. 53, No. 3, pp. 325-361. doi:https://doi.org/10.1353/wp.2001.0011

Ruta, M. - Venables, A. J. (2012), International Trade in Natral Resources: practice and policy. World Trade Organization: Economic Research and Statistics Division.

Sachs, J. D., - Warner, A. M. (1997), "Sources of slow growth in African economies", Journal of African economies, Vol. 6, No. 3, pp. 335-376. doi:https://doi.org/10.1093/oxfordjournals.jae.a020932

Sachs, J. - Warner, A. (1995), Natural Resource Abundance and Economic Growth (Working Paper 5398 ed.). Cambridge, MA: National Bureau of Economic Research.

Sala-i-Martin, X., - Subramanian, A. (2003), "Addressing the natural resource curse: Evidence from Nigeria", NBER Working Paper, 9804.

Schmider, E. - Ziegler, M. - Danay, E. - Beyer, L. - Buhner, M. (2010), "Is it really robust? Reinvestigating the robustness of ANOVA against violations of the normal distribution assumption", Methodology: European Journal of Research Methods for the Behavioral and Social Sciences, Vol. 6, 147-151. doi:https://doi.org/10.1027/1614-2241/a000016

Shleifer, A., - Vishny, R. W. (1993), "Corruption", The Quarterly Journal of Economics, Vol. 108, No. 3, pp. 599-617. doi:https://oi. org $/ 10.2307 / 2118402$

Silje, A. (2007), Corruption and oil: evidence from panel data, Unpublished Manuscript.

Soest, C. (2007), "How does neopatrimonialism affect the African states's revenues? The case of tax collection in Zambia", The Journal of Modern African Studies, Vol. 45, No. 4, pp. 621-645. doi:https://doi.org/10.1017/ S0022278X0700290X

Stijns, J.-P. C. (2005), "Natural resource abundance and economic growth 
revisited", Resource policy, Vol. 30, No. 2, pp. 107-130. doi:https://doi. org/10.1016/j.resourpol.2005.05.001

Stuckelberger, C. (2003), Continue Fighting Corruption: Experiences and Tasks of Churches and Development Agencies. Bread for all, The Series Impulse.

Tanzi , V. - Davoodi, H. R. (1998), Roads to nowhere: how corruption in public investment hurts growth (Vol. 12). International Monetary Fund.

Timms, M. (2016, July 21), "Nigeria urgently needs to tackle corruption and theft in its oil industry", World Finance, Retrieved January 11, 2019, from https://www.worldfinance.com/markets/nigeria-urgently-needs-to-tacklecorruption-and-theft-in-its-oil-industry

Transparency International (2017, January 27), Explanation of How Individual Country scores of the corruption perception index are calculated. Retrieved January 11, 2019, from Transparency.org: https://www.transparency.org/ news/pressrelease/explanation_of_how_individual_country_scores_of_the corruption_perceptions

Transparency International (2018), Corruption Perception Index 2017, Berlin, Germany: Transparency International

Transparency International (2018, January 12), What is Corruption? Retrieved January 11, 2019, from Transparency International Web site: https://www. transparency.org/what-is-corruption

Tsui, K. K. (2010), "Resource curse, political entry, and deadweight cost", Economics \& Politics, Vol. 22, No. 3, pp. 471-497. doi:https://doi.org/10.1111/ j.1468-0343.2010.00373.x

United Nations (2017), World Economic Situation and Prospects 2017, New York: United Nations publication

Van de Walle, N. (2005), Democratic Reform in Africa, United States: Lynne Rienner Publishers

van de Walle, N. (2007), The Path from Neopatrimonialism: Democracy and Clientelism in Africa Today, Merio Einaudi Center for International Studies

Van der Ploeg, F. - Poelhekke, S. (2009), "Volatility and the natural resource curse", Oxford Economic Papers, Vol. 60, No. 4, pp. 727-760. doi:https://doi. org/10.1093/oep/gpp027

Weeks, J. (2012), "The Resource Curse", Global Issues, Selection from CQ Researcher, 2012 edition, Sage Publications and CQ Press, pp. 359-378.

Wilhelm, P. G. (2002), "International Validation of the Corruption Perceptions Index: Implications for Business Ethics and Entrepreneurship Education", Journal of Business Ethics, Vol. 35, No. 2, pp. 177-189 doi:https://doi. org/10.1023/A:1013882225402

Wit, d. M., - Crookes, D. (2013), Oil Shock Vulnerabilities \& Impacts: Nigeria Case Study, United Kingdom Department for International Development 


\section{TABLES AND FIGURES}

Table 1 Mean Corruption Perception Index scores for fuel-exporting countries in Africa

\begin{tabular}{ll}
\hline Countries $^{\mathrm{a}}$ & Corruption $^{\mathrm{b}}$ \\
\hline Algeria & 33 \\
Angola & 19 \\
Cameroon & 25 \\
Chad & 20 \\
Congo, Rep. & 21 \\
Côte d'Ivoire & 36 \\
Egypt & 32 \\
Equatorial Guinea & 17 \\
Gabon & 32 \\
Libya & 17 \\
Nigeria & 27 \\
Sudan & 16 \\
\hline
\end{tabular}

${ }^{a}$ Fuel-exporting countries based on United Nations categorization (United Nations, 2017)

${ }^{b}$ Corruption score based on the corruption perception index (Transparency International, 2018)

Table 2 Mean Corruption Perception Index scores for non-fuel-exporting countries in Africa

\begin{tabular}{ll}
\hline Countries $^{\mathrm{a}}$ & Corruption $^{\mathrm{b}}$ \\
\hline Benin & 39 \\
Botswana & 61 \\
Burkina Faso & 42 \\
Burundi & 22 \\
Cabo Verde & 55 \\
Central African Republic & 23 \\
Comoros & 27 \\
Democratic Republic of Congo & 21 \\
Djibouti & 31 \\
Eritrea & 20 \\
Ethiopia & 35 \\
Gambia & 30 \\
Ghana & 40 \\
Guinea & 27 \\
Guinea Bissau & 17 \\
Kenya & 28 \\
Lesotho & 42 \\
Liberia & 31 \\
\hline
\end{tabular}

${ }^{a}$ Fuel-exporting countries based on United Nations categorization (United Nations, 2017)

${ }^{b}$ Corruption score based on the corruption perception index (Transparency International, 2018) 
Table 3 (Continued) Mean Corruption Perception Index scores for non-fuel-exporting countries in Africa

\begin{tabular}{ll}
\hline Countries $^{\mathrm{a}}$ & Corruption $^{\mathrm{b}}$ \\
\hline Madagascar & 24 \\
Malawi & 31 \\
Mali & 31 \\
Mauritania & 28 \\
Mauritius & 50 \\
Morocco & 40 \\
Mozambique & 25 \\
Namibia & 51 \\
Niger & 33 \\
Rwanda & 55 \\
Seo Tome and Principe & 46 \\
Senegal & 45 \\
Seychelles & 60 \\
Sierra Leone & 30 \\
Somalia & 9 \\
South Africa & 43 \\
South Sudan & 12 \\
Swaziland & 39 \\
Tanzania & 36 \\
Togo & 32 \\
Tunisia & 42 \\
Uganda & 26 \\
Zambia & 37 \\
Zimbabwe & 22 \\
\hline
\end{tabular}

a Fuel-exporting countries based on United Nations categorization (United Nations, 2017)

${ }^{b}$ Corruption score based on the corruption perception index (Transparency International, 2018)

Table 4 Descriptive statistics associated with the samples of the study

\begin{tabular}{lccccc}
\hline & $N$ & $M$ & $S D$ & Skew & Kurtosis \\
\hline $\begin{array}{l}\text { Fuel-exporting } \\
\begin{array}{l}\text { Countries } \\
\text { Non-fuel } \\
\text { exporting }\end{array}\end{array}$ & 12 & 24.58 & 7.20 & .32 & -1.59 \\
Countries & 42 & 34.23 & 12.26 & .30 & -.21 \\
\hline
\end{tabular}


Figure 1 Corruption Perception Index bar graph (with 95\% CIs)

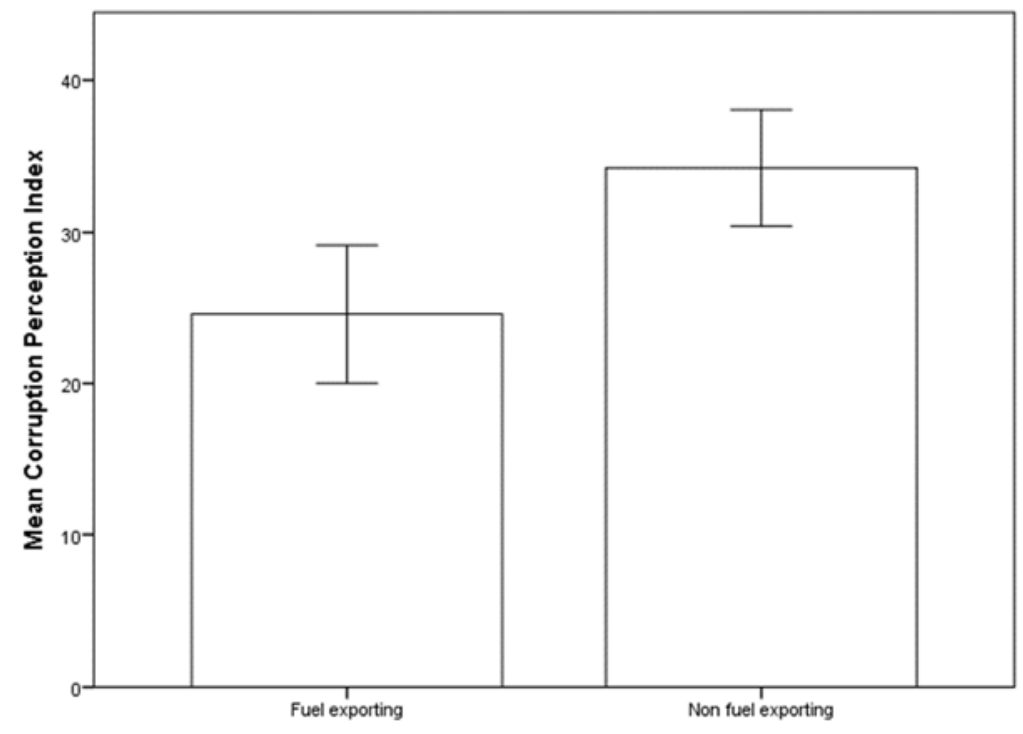


